\title{
Quantizing photosynthetic performance of phytoplankton using photosynthesis-irradiance response models
}

\section{Xiaolong Yang}

Fudan University https://orcid.org/0000-0002-9763-6122

Lihua Liu

Jinggangshan University

Zhikai Yin

Fudan University Department of Environmental Science and Engineering

\section{Xingyu Wang}

Fudan University Department of Environmental Science and Engineering

Shoubing Wang ( $\square$ bswang@fudan.edu.cn )

https://orcid.org/0000-0003-2696-2083

\section{Zipiao Ye}

Jinggangshan University

\section{Research}

Keywords: Phytoplankton, Photosynthetic performance, irradiance, photosynthesis-irradiance response model

Posted Date: December 20th, 2019

DOI: https://doi.org/10.21203/rs.2.19403/v1

License: (c) (i) This work is licensed under a Creative Commons Attribution 4.0 International License. Read Full License

Version of Record: A version of this preprint was published at Environmental Sciences Europe on February 26th, 2020. See the published version at https://doi.org/10.1186/s12302-020-00306-9. 
4 Xiaolong Yang ${ }^{\text {a }}$, Lihua Liu ${ }^{\text {b }}$, Zhikai Yin ${ }^{\text {a }}$, Xingyu Wang ${ }^{\text {a }}$, Shoubing Wang ${ }^{\text {a, }}$, Zipiao Ye 5

6

7

\section{Quantizing photosynthetic performance of phytoplankton using photosynthesis-irradiance response models} $\mathrm{b}, *$

${ }^{a}$ Department of Environmental Science and Engineering, Fudan University, 2005 Songhu road, Shanghai 200433, PR China

${ }^{\mathrm{b}}$ Institute of Biophysics, Maths \& Physics College, Jinggangshan University, 28 Xueyuan road, Ji'an 343009, PR China

* Corresponding author: Prof. Shoubing Wang

Fax: +86-21-65642297, E-mail: bswang@fudan.edu.cn

Corresponding author: Prof. Zipiao Ye

Fax: +86-796-8100488, E-mail: yezp@jgsu.edu.cn

Abstract

Background: Clarifying the relationship between photosynthesis and irradiance and accurately quantizing photosynthetic performance are of importance to calculate the productivity of phytoplankton, whether in aquatic ecosystems modelling or obtaining more economical production.

Results: The photosynthetic performance of seven phytoplankton species was 
characterized by four typical photosynthesis-irradiance $(P-I)$ response models. However, the differences were found between the returned values to photosynthetic characteristics by different $P-I$ models. The saturation irradiance $\left(I_{\text {sat }}\right)$ was distinctly underestimated by model 1 , and the maximum net photosynthetic rate $\left(P_{\mathrm{nmax}}\right)$ was quite distinct from its measured values, due to the asymptotic function of the model. Models 2 and 3 lost some foundation to photosynthetic mechanisms, that the returned $I_{\text {sat }}$ showed significant differences with the measured data. Model 4 for higher plants could reproduce the irradiance response trends of photosynthesis well for all phytoplankton species and obtained close values to the measured data, but the fitting curves exhibited some slight deviations under the low intensity of irradiance. Different phytoplankton species showed differences in photosynthetic productivity and characteristics. P. subcordiformis showed larger intrinsic quantum yield $(\alpha)$ and lower $I_{\text {sat }}$ and light compensation point $\left(I_{\mathrm{c}}\right)$ than $D$. salina or I. galbana. Microcystis sp., especially $M$. aeruginosa with the largest $P_{\mathrm{nmax}}$ and $\alpha$ among freshwater phytoplankton strains, exhibited more efficient light use efficiency than two species of green algae.

Conclusions: The present work will be useful both to describe the behavior of different phytoplankton in a quantitative way as well as to evaluate the flexibility and reusability of $P$-I models. Meanwhile we believe this research could provide important insight into the structure changes of phytoplankton communities in the aquatic ecosystems.

Keywords: Phytoplankton; Photosynthetic performance; irradiance; photosynthesisirradiance response model 
Phytoplankton are a key functional component of aquatic ecosystems, play a pivotal role in biogeochemical cycles [1]. In particular, marine phytoplankton, as the principal driving force of ocean carbon cycles and energy flows, fix approximately 50 gigatons of inorganic carbon annually, almost half of the total global primary production $[2,3]$. They show higher $\mathrm{CO}_{2}$ fixation rates and higher biomass productivity than any other photosynthetic organism [3]. With increasing concentration of $\mathrm{CO}_{2}$ concentrations in the atmosphere and growing climate warming, an accurate estimate of photosynthetic productivity of phytoplankton becomes ever more important for modelling primary production and structure changes of phytoplankton communities in aquatic ecosystems, especially eutrophic lakes (e.g., Taihu, Erie, Winnipeg lake) and estuaries (e.g., Yangtze River).

Clarifying the relationship between photosynthesis and irradiance is a basis to evaluate 
On the other hand, phytoplankton cells are rich in proteins, polysaccharides, lipids, vitamins, and polyunsaturated fatty acids, which have stirred up great attention as a promising potential feedstock for biofuel, nutraceuticals, animal and aquaculture feed production $[10,14]$. Many species have been used for commercial development, such as Dunaliella salina, Isochrysis galbana, Spirulina (or Arthrospira), Haematococcus pluvialis, and Scenedesmus obliquus $[2,6,10]$. Almost all fishes, bivalve molluscs, and crustaceans primarily graze on phytoplankton to build immunity against diseases during their early larval stages [12]. However, large-scale production of phytoplankton has rarely been successful, with no more than $1 \mathrm{~g} \mathrm{DW} \mathrm{L}^{-1}$ biomass that is mainly limited by the inefficiency of photosynthesis in high-cell density cultivation $[11,14,15]$. The photosynthetic parameters can be seen as indicators to achieve sustainable carbon assimilation and TAG accumulation in Isochrysis zhangjiangensis [8]. Therefore, accurately quantizing photosynthetic performance is crucial for more economical integration of production management and operation of industrial-scale phytoplankton culture systems [16].

The response curve of photosynthesis to irradiance $(P-I)$ is frequently used to characterize photosynthetic performance by fitting experimental data (measured as oxygen evolution or carbon uptake) with $P-I$ models [17]. Obtained photosynthetic parameters, including the maximum net photosynthetic rate $\left(P_{\mathrm{nmax}}\right)$, the optimal intensity of irradiance $\left(I_{\mathrm{sat}}\right)$, and the dark respiration rate $\left(R_{\mathrm{d}}\right)$ can be regarded as indicator to evaluate the response of phytoplankton to meet environmental changes. A variety of $P-I$ models for phytoplankton have been established in the last few decades [18-30]. Although many recent models are suggested based to "old models" established in the 70s and 80s and have some contributions to improve, the most extensive application are still found in 
97 those "old models" [31-35]. For example, an examination of the literature overwhelmingly reveals in excess of 1950 papers on the model proposed by Platt et al.[20]. This is most probably because they are simpler than those new models with complex parameters and any new model must take many years to be fully adopted. Higher plant and phytoplankton possess similar photosynthetic systems. Ye et al. developed a model for higher plants that parameterizes the core characteristics of the irradiance response, including solar energy absorption of photosynthetic pigment molecules, energy transfer, and electron transport between photosynthetic apparatuses[36]. This has been widely applied in rice, wheat, soybean, sunflower and other plants [37, 38].

The objective of this study was to determine the various relationships between the photosynthetic productivity of phytoplankton and irradiance intensity and investigate the reliability of $P$-I models to estimate the photosynthetic performance for phytoplankton. We selected the rather extensive range of phytoplankton, including three isolated from the ocean and four from lakes, to measure their photosynthetic oxygen evolution under different irradiance intensity. Obtained $P-I$ data were fitted by using $P-I$ model for quantization the photosynthetic performances. One $P$-I model for higher plants developed by Ye et al.[36] (it was represented as model 4 in this study) was first used to compare against three most widely applied models for phytoplankton (them were represented as models 1,2 and 3 in this study).

\section{Materials and methods}

\section{Phytoplankton cultivation}

The three strains of marine phytoplankton (Isochrysis galbana, Dunaliella salina and Platymonus subcordiformis) isolated from East China Seas were grown aseptically in f/2 medium. The four strains of freshwater phytoplankton (Microcystis aeruginosa FACHB- 

Sciences (Wuhan, China) and cultivated in BG11 medium. The cultures were illuminated by cool white fluorescent bulbs $\left(60 \mu \mathrm{mol}\right.$ photons $\left.\mathrm{m}^{-2} \mathrm{~s}^{-1}\right)$ with a photoperiod of $12 \mathrm{~h}$ per day at $26 \pm 1{ }^{\circ} \mathrm{C}$.

\section{Measurement of photosynthetic oxygen evolution}

After seven to ten days of incubation, the photosynthetic oxygen-evolving rate of microalgal cells reaching the exponential growth phase was determined using a biooxygen metre (Yaxin-1151, Beijing Yaxinliyi Science and Technology Co., Ltd., China). Eight-mL cell suspensions of each strain were exposed to increasing orders of irradiance intensity $(0,25,50,100,150,200,300,400,500,600,800,1000$, and $1200 \mu$ mol photons $\mathrm{m}^{-2} \mathrm{~s}^{-1}$ ), given by a digital LED light source (YX-11LA, Beijing Yaxinliyi Science and 
145 (Spectrum Instruments, Shanghai, China) according to the method of Jeffrey \& 146 Humphrey [39]. One-mL cultures of each strain were taken and preserved in Lugol's 147 iodine solution for counting algal cells by a haemocytometer. Each test was conducted in 148 triplicate.

\section{Model description}

150

\section{Model 1}

The light dependence of the net photosynthetic rate $\left(P_{\mathrm{n}}\right)$ is expressed as [22]:

$$
P_{\mathrm{n}}=P_{\mathrm{n} \max } \tanh \left(\frac{\alpha I}{P_{\mathrm{n} \max }}\right)-R_{\mathrm{d}}
$$

where $P_{\mathrm{n}}\left(\mu \mathrm{mol} \mathrm{O} \mathrm{mg}^{-1} \mathrm{Chl} a \mathrm{~h}^{-1}\right)$ is the chlorophyll $a$-normalised net photosynthetic rate at irradiance $I, P_{\text {nmax }}\left(\mu \mathrm{mol} \mathrm{O} \mathrm{O}_{2} \mathrm{mg}^{-1} \mathrm{Chl} a \mathrm{~h}^{-1}\right)$ is the light-saturated maximum rate of photosynthesis, $\alpha\left(\mu \mathrm{mol} \mathrm{O} \mathrm{mg}^{-1} \mathrm{Chl} a \mathrm{~h}^{-1} / \mu \mathrm{mol}\right.$ photons $\left.\mathrm{m}^{-2} \mathrm{~s}^{-1}\right)$ is the light-limited initial slope, and $R_{\mathrm{d}}\left(\mu \mathrm{mol} \mathrm{O} \mathrm{mg}^{-1} \mathrm{Chl} a \mathrm{~h}^{-1}\right)$ is the dark respiration rate.

The saturation irradiance $\left(I_{\mathrm{sat}}, \mu \mathrm{mol}\right.$ photons $\left.\mathrm{m}^{-2} \mathrm{~s}^{-1}\right)$ corresponding to the lightsaturated maximum rate $\left(P_{\mathrm{nmax}}\right)$ of photosynthesis is calculated as [1]:

$$
I_{\mathrm{sat}}=\frac{P_{\mathrm{nmax}}-R_{\mathrm{d}}}{\alpha}
$$

But the analytic solution of the light compensation point $\left(I_{\mathrm{c}}, \mu \mathrm{mol}\right.$ photons $\left.\mathrm{m}^{-2} \mathrm{~s}^{-1}\right)$ can not be obtained by equation (1). In order to obtain $I_{\mathrm{c}}$, Kok effect [40] must be ignored here, and $I_{\mathrm{c}}$ can be calculated as [19]:

$$
I_{\mathrm{c}}=\frac{R_{\mathrm{d}}}{\alpha}
$$

The photosynthetic quantum efficiency $\left(P_{\mathrm{n}}{ }^{\prime}, \mu \mathrm{mol} \mathrm{O} \mathrm{O}_{2} \mu \mathrm{mol}_{\text {photons }}{ }^{-1}\right)$ is calculated as:

$$
P_{\mathrm{n}}^{\prime}=\frac{\alpha}{\cosh ^{2} \frac{\alpha I}{P_{\mathrm{nmax}}}}
$$

\section{Model 2}

The light dependence of $P_{\mathrm{n}}$ is expressed as $[19,20]$ : 


$$
P_{\mathrm{n}}=P_{\mathrm{s}}\left[1-\exp \left(-\frac{\alpha I}{P_{\mathrm{s}}}\right)\right] \exp \left(-\frac{\beta I}{P_{\mathrm{s}}}\right)-R_{\mathrm{d}}
$$

169 where $P_{\mathrm{n}}$ is the chlorophyll $a$-normalised net photosynthetic rate at irradiance $I ; P_{\mathrm{s}}$ is the 170 parameter reflecting the maximum, potential, light-saturated, rate of photosynthesis; $\alpha$ is the light-limited initial slope; $\beta$ is the dimensionless parameter reflecting the photoinhibition process; and $R_{\mathrm{d}}$ is the dark respiration rate. The $I_{\text {sat }}$ is calculated as:

$$
I_{\mathrm{sat}}=\frac{P_{\mathrm{s}}}{\alpha} \ln \frac{\alpha+\beta}{\beta}
$$

The $P_{\text {nmax }}$ can be calculated as:

However, the analytic solution of $I_{\mathrm{c}}$ can not be obtained by equation (5). To obtain $I_{\mathrm{c}}$,

Model 3

$$
P_{\mathrm{nmax}}=P_{\mathrm{S}}\left(\frac{\alpha}{\alpha+\beta}\right)\left(\frac{\beta}{\alpha+\beta}\right)^{\frac{\beta}{\alpha}}-R_{\mathrm{d}}
$$

the Kok effect must be ignored here, and $I_{\mathrm{c}}$ can be calculated as:

$$
I_{\mathrm{c}}=\frac{R_{\mathrm{d}}}{\alpha}
$$

The photosynthetic quantum efficiency is calculated as:

$$
P_{\mathrm{n}}^{\prime}=\exp \left(-\frac{\beta I}{P_{\mathrm{s}}}\right)\left\{\alpha \exp \left(-\frac{\alpha I}{P_{\mathrm{s}}}\right)-\beta\left[1-\exp \left(-\frac{\alpha I}{P_{\mathrm{s}}}\right)\right]\right\}
$$

Here $P_{\mathrm{n}}$ is the chlorophyll $a$-normalised net photosynthetic rate at irradiance $I ; \alpha$ and $\beta$ are the fundamental parameters, nondimensional; and $R_{\mathrm{d}}$ is the dark respiration rate. The reciprocal of $\gamma$ is the light-limited initial slope. 


$$
I_{\mathrm{sat}}=\sqrt{\frac{\gamma}{\alpha}}
$$

$190 \quad P_{\mathrm{nmax}}$ is given by:

$$
P_{\operatorname{nmax}}=\frac{1}{\beta+2 \sqrt{\alpha \gamma}}-R_{d}
$$

192 When $P_{\mathrm{n}}=0, I_{\mathrm{c}}$ is given as follows,

$$
I_{\mathrm{c}}=\frac{1-\beta R_{d}+\sqrt{\left(1-\beta R_{d}\right)^{2}-4 \alpha \gamma R_{d}}}{2 \alpha R_{d}}
$$

The photosynthetic quantum efficiency is calculated as:

195

$$
P_{\mathrm{n}}^{\prime}=\frac{\gamma-\alpha I^{2}}{\left(\gamma+\beta I+\alpha I^{2}\right)^{2}}
$$

196

197

198

199

200

201

202

Model 4

The light dependence of $P_{\mathrm{n}}$ is expressed as [36]:

$$
P_{\mathrm{n}}=\alpha \frac{1-\beta I}{1+\gamma I} I-R_{\mathrm{d}}
$$

Here $P_{\mathrm{n}}$ is the chlorophyll $a$-normalised net photosynthetic rate at irradiance $I, \alpha$ is the initial slope of the $P_{\mathrm{n}}-I$ response curve, $\beta$ and $\gamma$ are the nondimensional parameters reflecting photoinhibition and light saturation, respectively, and $R_{\mathrm{d}}$ is the dark respiration rate.

$I_{\text {sat }}$ is calculated as:

$$
I_{\text {sat }}=\frac{\sqrt{\frac{(\beta+\gamma)}{\beta}-1}}{\gamma}
$$

$P_{\text {nmax }}$ is obtained by:

$$
P_{\mathrm{n} \max }=\alpha\left(\frac{\sqrt{\beta+\gamma}-\sqrt{\beta}}{\gamma}\right)^{2}-R_{d}
$$

When $P_{\mathrm{n}}=0, I_{\mathrm{c}}$ is given as follows,

$$
I_{\mathrm{c}}=\frac{\alpha-\gamma R_{d}-\sqrt{\left(\alpha-\gamma R_{d}\right)^{2}-4 \alpha \beta R_{d}}}{2 \alpha \beta}
$$


The photosynthetic quantum efficiency is calculated as:

$$
P_{\mathrm{n}}^{\prime}=\alpha \frac{1-2 \beta I-\beta \gamma I^{2}}{(1+\gamma I)^{2}}
$$

\section{Statistical analysis}

$P-I$ data were fitted using SPSS version 24.0 using nonlinear, least-squares fitting based on the Levenberg-Marquardt algorithm. Duncan's post hoc tests $(p<0.05)$ were performed to establish differences among fitted results from model 1, model 2, model 3 and model 4. Data were reported as the means and standard errors in the calculations. Goodness of fit of the mathematical models to experimental data was assessed using the adjusted coefficient of determination $\left(R^{2}\right)$.

\section{Results}

\section{Comparison of different $P$-I models of production curves}

Applying different values of the fundamental parameters to the model, the differences in the characteristics of production curves among model 2, model 3 and model 4 were compared, save for model 1 , without consideration of light-inhibition at high irradiant intensity. Assuming that the initial slope $\alpha$ was 0.5 (the initial slope of the curve equals the reciprocal of $\gamma$ in model 3), increasing values of the light-saturated or photoinhibition parameters decreased $P_{\mathrm{nmax}}$ of the curve and increased the magnitude of inhibition in three types (Fig. 1b-f), which indicated that they could closely reproduce the trend of the $P_{\mathrm{n}}-I$ curve. However, although $P_{\mathrm{s}}$ is defined as being associated with $P_{\mathrm{nmax}}$ in model 2 , the given value of $P_{\mathrm{s}}$ was over $30 \sim 125 \%$ of $P_{\mathrm{nmax}}$, for which the biological implication is difficult to understand (Fig. 1a). However, in Fig. 1c, $I_{\text {sat }}$ was kept constant value versus the change of $\beta$ because $I_{\text {sat }}$ was barely related to $\alpha$ or $\gamma$, according to Eqn. 16 . In fact, greater $\beta$ values were associated with greater bends of the curve, indicating saturation occurred more easily. Thus, Fig. 1c is clearly contradictory to the basis of photosynthetic 
physiology.

\section{The morphological and growth characteristics of phytoplankter}

The morphology of the cultured cells was observed under a 600x optical microscope.

Cells were mostly spherical, at $4.3 \sim 10 \mu \mathrm{m}$ in diameter, and grew singly, except for $S$.

obliquus. The Chl $a$ contents were $1.647 \pm 0.015,2.778 \pm 0.077,2.297 \pm 0.027,1.320$ $\pm 0.005,1.739 \pm 0.012,1.318 \pm 0.027$ and $4.158 \pm 0.077 \mathrm{mg} \mathrm{L}^{-1}$ for cultures of I. galbana D. salina, P. subcordiformis, M. aeruginosa, M. wesenbergii, S. obliquus and Chlorococcum sp., respectively (Table 1), which was used to normalize the photosynthetic oxygen-producing rate of phytoplankton. This normalization will reduce the variability of photosynthetic oxygen-producing rates as a result of differences in biomass, facilitating the comparison of photosynthetic performance. The Chl $a$ content per cell of I. galbana, D. salina, P. subcordiformis, M. aeruginosa, M. wesenbergii, $S$. obliquus, and Chlorococcum sp. was $2.570 \pm 0.042,27.118 \pm 1.151,22.931 \pm 0.563$, $1.972 \pm 0.044,2.404 \pm 0.031,9.126 \pm 0.600$, and $4.578 \pm 0.106 \mathrm{ng} 10^{4}$ cells $^{-1}$, respectively.

\section{$P-I$ curve and $P^{\prime}-I$ curve of freshwater phytoplankton}

The $P-I$ curves for M. aeruginosa, M. wesenbergii, S. obliquus and Chlorococcum sp. are given in Fig. 3A. For almost all strains, $P_{\mathrm{n}}$ increased rapidly with $I$ under low irradiance intensity, and reached saturation at $400 \mu \mathrm{mol}$ photons $\mathrm{m}^{-2} \mathrm{~s}^{-1} \cdot P_{\mathrm{n}}$ exhibited a sharp decline for M. aeruginosa, M. wesenbergii, and S. obliquus yet only a slow decline for Chlorococcum sp. with the increasing I. As was observed for marine phytoplankton, all curves exhibited photoinhibition above the $I_{\text {sat }}$, but in addition to those estimated by model 1 . 
despite having nearly identical $P-I$ curves, there were some differences in the photosynthetic parameters obtained by the different models (Table 3). The values of $P_{\text {nmax }}$ obtained by models 2,3 and 4 were close to their measured values (approximately 290.83 $\mu \mathrm{mol} \mathrm{O}_{2} \mathrm{mg}^{-1}$ Chl $a \mathrm{~h}^{-1}$ for M. aeruginosa and $201.29 \mu \mathrm{mol} \mathrm{O}_{2} \mathrm{mg}^{-1} \mathrm{Cha} \mathrm{h}^{-1}$ for $M$. wesenbergii), with $<5 \%$ of errors. Nevertheless, the values of $I_{\text {sat }}$ calculated by models 2 and 3 for M. aeruginosa and M. wesenbergii were far below their measured values, with significant differences $(p<0.05)$. For $S$. obliquus, the values of $P_{\text {nmax }}$ obtained by models 2,3 and 4 were just under $1 \%$ of the measured value, yet all the corresponding $I_{\text {sat }}$ were over the measured value. The $P_{\text {nmax }}$ calculated by models 2,3 and 4 for Chlorococcum sp. were $75.25 \pm 3.79,76.15 \pm 3.89$ and $74.59 \pm 4.23 \mu \mathrm{mol} \mathrm{O}_{2} \mathrm{mg}^{-1} \mathrm{Chl} a \mathrm{~h}^{-1}$, respectively, while the $I_{\text {sat }}$ were $311.04 \pm 17.27,339.85 \pm 15.19$ and $396.06 \pm 15.9 \mu$ mol photons $\mathrm{m}^{-2} \mathrm{~s}^{-}$ ${ }^{1}$, respectively. No significant differences were found between the $I_{\text {sat }}$ calculated by model 4 and the measured data $(p<0.05)$. The photosynthetic parameters obtained by model 1 were still far from the measured data for these freshwater phytoplankton; above all, the $I_{\text {sat }}$ were seriously underestimated. For $\alpha$, the estimated by model 4 was the highest for all strains among the other three models. There were no significant differences in the estimation of $I_{\mathrm{c}}$ or $R_{\mathrm{d}}$ among each model. Fig. 3B indicates that the nonlinear change of $P^{\prime}{ }_{n}$ as $I$ in four species of freshwater phytoplankton was similar to that in marine phytoplankton.

\section{$P$-I curve and $P^{\prime}-I$ curve of marine phytoplankton}

The $P$-I curves of I. galbana, D. salina and P. subcordiformis are shown in Fig. 2A, and obvious differences were observed among strains. $P_{\mathrm{n}}$ increased gradually with $I$ towards saturation, which was at $800 \mu \mathrm{mol}$ photons $\mathrm{m}^{-2} \mathrm{~s}^{-1}$ for I. galbana. However, for D. salina and $P$. subcordiformis, $P_{\mathrm{n}}$ increased steeply, almost linearly, within low 
irradiance intensity (below $200 \mu \mathrm{mol}$ photons $\mathrm{m}^{-2} \mathrm{~s}^{-1}$ ), and it decreased rapidly when it reached the maximum value. All curves stopped above the $I_{\text {sat }}$, excluding those produced by model 1 , which indicates the presence of photoinhibition.

Differences were also observed in photosynthetic characteristic parameters calculated by the four types of models (Table 2). Model 1 either overestimated $P_{\text {nmax }}$ or underestimated $I_{\text {sat, }}$, and these values showed significant differences with their measured values $(p<0.05)$ for three strains of marine phytoplankton. The $P_{\text {nmax }}$ obtained by models 2, 3 and 4 for I. galbana were $97.45 \pm 3.02,97.55 \pm 3.37$ and $98.33 \pm 3.20 \mu \mathrm{mol} \mathrm{O}_{2} \mathrm{mg}^{-1}$ Chl $a \mathrm{~h}^{-1}$, respectively. The $I_{\text {sat }}$ corresponding to $P_{\text {nmax }}$ were $709.60 \pm 26.89,699.26 \pm$ $32.19,766.17 \pm 24.38 \mu \mathrm{mol}$ photons $\mathrm{m}^{-2} \mathrm{~s}^{-1}$, respectively. Despite no significant differences in either estimated $P_{\text {nmax }}$ or $I_{\text {sat }}$ by the three models $(p>0.05)$, model 4 fitted the values to the measured values with $<5 \%$ of errors. For $D$. salina, the $P_{\text {nmax }}$ estimated by models 2,3 and 4 were $113.73 \pm 6.24,114.45 \pm 6.24$ and $113.31 \pm 5.87 \mu \mathrm{mol} \mathrm{O}_{2} \mathrm{mg}^{-1}$ Chl $a \mathrm{~h}^{-1}$, respectively, while the $I_{\text {sat }}$ obtained by model 2 and model 3 were notably lower than the measured value, with significant differences $(p<0.05)$. The $I_{\text {sat }}$ obtained by model 4 was $510.24 \pm 2.92 \mu \mathrm{mol}$ photons $\mathrm{m}^{-2} \mathrm{~s}^{-1}$, which was quite similar to the measured value (approximately $500 \mu \mathrm{mol}$ photons $\mathrm{m}^{-2} \mathrm{~s}^{-1}$ ). The values of $P_{\mathrm{nmax}}$ estimated by models 2, 3 and 4 for $P$. subcordiformis were $94.64 \pm 6.65,95.59 \pm 6.63$, and $92.20 \pm 6.56 \mu \mathrm{mol}$ $\mathrm{O}_{2} \mathrm{mg}^{-1} \mathrm{Chl} a \mathrm{~h}^{-1}$, respectively; however, the calculated $I_{\text {sat }}$ were significantly higher than the measured values $(p<0.05)$, likely because of the rapid increase of $P_{\mathrm{n}}$ during lowintensity irradiance. The initial slope of the $P-I$ curve $\alpha$, namely, the intrinsic quantum yield, estimated by model 4 was higher for all strains than those estimated by other models, with significant differences $(p<0.05)$ for $D$. salina and $P$. subcordiformis. 
or oxygen evolution by a photosynthetic apparatus driven by absorbed photon energy, that is, the conversion efficiency of absorbed solar energy into chemical energy. Fig. 2B shows that the quantum yield calculated by models 2,3 and 4 for I. galbana, D. salina and $P$. subcordiformis decreased as $I$ increased, until it was equal to zero at the $I_{\text {sat }}$ point. Subsequently, it became negative as $I$ increased, which also reveals why $P_{\mathrm{n}}$ decreased as $I$ increased above $I_{\text {sat. }}$. However, the values of $P^{\prime}{ }_{\mathrm{n}}$ obtained by model 1 were always greater than zero with increasing $I$ due to the asymptotic function in this model.

\section{Discussion}

Photosynthesis is not only a biochemical process achieved by photosynthetic apparatuses, it also contains a biophysical process [5, 9, 41]. As shown in Fig. 4, photosynthetic pigment molecules (Chl), such as Chlorophyll $a$ and $b$ and carotenoids, absorb solar energy, which induces them into an excited state $\left(C h l^{*}\right)$. The largest amount of exciton binding energy is transferred to the photochemical reaction centres $\left(P_{680}\right.$ and $P_{700}$ ), where charge separation occurs and produces electrons $\left(\mathrm{e}^{-}\right)$and accompanied by the splitting of water into $P_{680}$ *. Other energy is transformed into fluorescence and heat [5, 17, 25, 28, 29]. Chl* conducts de-excitation by photochemistry, non-radiation heat dissipation, and chlorophyll fluorescence then able to accept new photons, yet the process depend on the lifetime of $C h l$ in the excited state [41, 42]. The released electrons pass through pheophytin to the first electron acceptor $\mathrm{Q}_{\mathrm{A}}$ and are ultimately transferred via a series of electron carriers to photosystem I, thereby producing ATP and reducing NADPH to driving photosynthetic carbon fixation and respiratory carbon oxidation $[5,26]$. Although a variety of $P-I$ models have been established and used to fit the $P-I$ curve for estimating photosynthetic performance and responses to environment changes for phytoplankton [18-20, 22-30,43], many of them were not built based on the 
photosynthetic mechanism.

The exponential model established by Webb et al. [23] and model 1 are still applied extensively for phytoplankton [31-35] even though they lack photoinhibition function. For example, Ma et al. [34] indicated that the $P_{n \max }$ calculated by model 1 for $M$. aeruginos $a$ FACHB-905 and M. aeruginosa FACHB-469 were $253.92 \pm 6.79$ and 231.32 $\pm 6.40 \mu \mathrm{mol} \mathrm{O} \mathrm{mg}^{-1} \mathrm{Chl} a \mathrm{~h}^{-1}$, respectively, at $25^{\circ} \mathrm{C}$, yet the corresponding $I_{\text {sat }}$ were only $92.71 \pm 7.86$ and $88.61 \pm 3.22 \mu \mathrm{mol}$ photons $\mathrm{m}^{-2} \mathrm{~s}^{-1}$, respectively. Furthermore, the shape of their $P-I$ curves did not appear to decline above $I_{\text {sat. }}$ In our study, the values of $\alpha, P_{\text {nmax }}$ and $I_{\text {sat }}$ fitted by model 1 showed significant differences with those obtained by other models $(p<0.05)$; either $P_{\mathrm{nmax}}$ or $I_{\mathrm{sat}}$ were distinct from their measured data for seven strains of phytoplankton (including M. aeruginosa FACHB-905), which suggests that an insufficient irradiance would be supplied to the cultivation if the $I_{\text {sat }}$ was used as the optimal intensity of irradiance.

To describe the entire range of light levels of phytoplankton, Platt et al. $[19,20]$ proposed another empirical model with a photoinhibition function (model 2 in this study). Superficially, the $P$ - $I$ curves fitted by model 2 seem to be perfect as other studies $[44,45]$, but the value of $P_{\mathrm{s}}$ among the fitted results was notably higher than the value of $P_{\mathrm{nmax}}$ in seven phytoplankton strains, whether $\beta>0$ or $\beta=0$ (Table 4). However, $P_{\mathrm{nmax}}=P_{\mathrm{s}}$ by Eqn. 7, where there was no inhibition at $\beta=0$, and the fitting curves were similar to model 1 (Fig. 6). Additionally, $P_{\mathrm{s}}$ appeared to fluctuate at $\beta>0$, which indicates the presence of inhibition among I. galbana, M. aeruginosa, M. wesenbergii and S. obliquus. This reveals a clear disagreement with the definition of $P_{\mathrm{s}}$ that characterizes the output of dark reactions of photosynthesis in model 2 . Therefore, improvement of model 2 is needed to redefine the biological implication of some fundamental parameters according to the 
photosynthesis mechanism.

Compared with previous models, model 3 is no longer just a mathematical equation describing the dependence of the photosynthetic rate on irradiance intensity. Its foundation is an assumption of "photosynthetic factories" (PSF) on physiological mechanisms proposed by Crill [21]. A PSF that is regarded as a combination of photosystem I (PSI) and PSII conducts one unit of light to generate one unit of photosynthetic product. And Eilers and Peeters assumed that the process of photosynthesis is modeled by changes of the states of PSF from the resting state to the activated and inhibited state $[17,18]$. Model 3 yielded a good-fitting curve for the $P-I$ data of all strains of phytoplankton in this study, and the returned values for $P_{\text {nmax }}, I_{\mathrm{c}}$, and $R_{\mathrm{d}}$ were close to their measured values, except for $I_{\text {sat }}$, which showed a large deviation ( $p$ $<0.05)$. Meanwhile, Fig. 1c shows that the $I_{\text {sat }}$ of curve did not change with the value of $\beta$. This may be because there is no assumption of the capture of solar energy, energy transfer process, or electron transport process from PSII to Cytb6f and then to PSI.

Although differences between higher plants and phytoplankton are observed in photosynthetic antenna system and photosynthetic components $[10,16]$, in present study the $P$-I curves of all phytoplankton species fitted by model 4 , which be developed for higher plants, were good and the returned values were also close to the measured data. This reveals that $P-I$ models for higher plants are applicable for phytoplankton. Acquiring an accurate and optimal parameter for irradiance intensity is essential to achieve high biomass of phytoplankton in production. Irradiance is rapidly attenuated during high-cell density cultivation of phytoplankton $[14,25]$. Variation in the pigment composition of light harvesting complexes with irradiance intensity has been observed in most species of phytoplankton [4, 5]. Irradiance intensity also regulates the accumulation of 
triacylglycerols and carbohydrates $[6,7]$. Note that obtained $I_{\text {sat }}$ by model 4 was closer to the measured value than other three models. The differences between the returned values for $P_{\mathrm{nmax}}, I_{\mathrm{c}}$, and $R_{\mathrm{d}}$ by model 4 and their measured values were slightly larger than those by model 3, without significant differences $(p>0.05)$. The fitting curves by model 4 for P. subcordiformis, M. aeruginosa, M. wesenbergii, and Chlorococcum sp. exhibited some deviations under low intensity of irradiance, likely because the model targeted higher plants, which showed higher light dependence than phytoplankton.

In meso- and eutrophic water bodies, irradiance or temperature is a key factor affecting changes of phytoplankton community composition, especially for those that become the dominant population between cyanobacteria and green algae [46]. The results of this study explicitly demonstrate that $M$. aeruginos $a$ and $M$. wesenbergii had high intrinsic quantum efficiency $(\alpha)$, while their $\mathrm{Chl} a$ content per cell was lower than that of both $S$. obliquus and Chlorococcum sp., indicating the efficient light harvesting and use for $M$. aeruginos $a$ and $M$. wesenbergii. In addition, almost two times less $\alpha$ than both S. obliquus and Chlorococcum sp., and the largest $P_{\mathrm{nmax}}$ were found in M. aeruginosa. However, $M$. aeruginos $a$ is the main contributor of notorious bloom-forming cyanobacteria in global freshwater bodies, such as Dianchi Lake in China [47]. These results reveal the underlying physiological basis of photosynthesis of Microcystis with lower "critical light intensity", and provide important insights into the management and control of cyanobacteria in changing lakes and estuarine waters.

I. galbana and D. salina are applied world-wide to generate biofuels due to their rich lipids (lipid levels between 23 and 55\% by weight of dry biomass), and they are also commonly cultivated with P. subcordiformis (lipid levels between 20 and $30 \%$ by weight of dry biomass) for aquaculture in China, Japan, Australia, and southeast Asia [14, 48]. 

photosynthetic productivity of each strain reach as high as possible during production. The comparison revealed that, although the $P_{\text {nmax }}$ lay between $I$. galbana and $P$. subcordiformis, other photosynthetic characteristic parameters showed great differences. The smallest $\alpha$ and highest $I_{\mathrm{c}}$ were found in I. galbana, which meant a low efficiency of light capture and use for I. galbana because the intrinsic quantum yield represents the numbers of photosynthetic electrons required to assimilate one $\mathrm{CO}_{2}$ molecule [8]. In contrast, the largest $\alpha$ and lowest $I_{\text {sat }}$ and $I_{\mathrm{c}}$ were in $P$. subcordiformis, although it possesses lower Chl $a$ content per cell than that of D. salina. Consequently, the ranking of light-dependence in descending order was P. subcordiformis, D. salina, and I. galbana. Under co-culture conditions, a gradient of irradiance from low to mid to high can be supplied in one photoperiod.

\section{Conclusions}

415 Our study showed that significant differences were found between the returned values 416 to photosynthetic characteristics by models 1, 2 and 3, some parameters (e.g., $\left.I_{\text {sat }}\right)$ were 417 distinctly different to the measured data. Model 4 for higher plants reproduced the irradiance response trends of photosynthesis well, was applicable for phytoplankton, but more studies are required to investigate its flexibility and reusability. Differences in 420 photosynthetic performance were observed among phytoplankton species. $P$. 421 subcordiformis showed higher light-dependence than D. salina and I. galbana, while $M$. aeruginosa and $M$. wesenbergii exhibited more efficient light use than S. obliquus and changes of phytoplankton communities in the aquatic ecosystem, especially in those 
eutrophic lakes and estuaries.

426

427

\section{List of abbreviations}

428 Photosystem I (PSI);

429 Photosystem II (PSII);

430 Reactive oxygen species (ROS);

431 Response of photosynthesis to irradiance $(P-I)$;

432 Photosynthetic factories (PSF);

433 Chlorophyll $a(\mathrm{Chl} a)$;

434 Irradiance intensity $\left(I, \mu \mathrm{mol}\right.$ photons $\left.\mathrm{m}^{-2} \mathrm{~s}^{-1}\right)$;

435 Net photosynthetic rate at irradiance $I\left(P_{\mathrm{n}}, \mu \mathrm{mol} \mathrm{O} \mathrm{mg}^{-1} \mathrm{Cha} \mathrm{h}^{-1}\right)$;

436 Maximum net photosynthetic rate $\left(P_{\mathrm{nmax}}, \mu \mathrm{mol} \mathrm{O} \mathrm{mg}^{-1} \mathrm{Cha} \mathrm{h}^{-1}\right)$;

437 Saturation irradiance $\left(I_{\mathrm{sat}}, \mu \mathrm{mol}\right.$ photons $\left.\mathrm{m}^{-2} \mathrm{~s}^{-1}\right)$;

438 Light-limited initial slope $\left(\alpha, \mu \mathrm{mol} \mathrm{O} \mathrm{mg}^{-1} \mathrm{Cha} \mathrm{h}^{-1} / \mu \mathrm{mol}\right.$ photons $\left.\mathrm{m}^{-2} \mathrm{~s}^{-1}\right)$;

439 Light compensation point $\left(I_{\mathrm{c}}, \mu \mathrm{mol}\right.$ photons $\left.\mathrm{m}^{-2} \mathrm{~s}^{-1}\right)$;

440 Dark respiration rate $\left(R_{\mathrm{d}}, \mu \mathrm{mol} \mathrm{O} \mathrm{mg}^{-1} \mathrm{Cha} \mathrm{h}^{-1}\right)$;

441 Adjusted coefficient of determination $\left(R^{2}\right)$;

442 Photosynthetic quantum efficiency $\left(P_{\mathrm{n}}{ }^{\prime}, \mu \mathrm{mol} \mathrm{O}_{2} \mu \mathrm{mol}\right.$ photons $\left.^{-1}\right)$;

443 Response of photosynthetic quantum efficiency to irradiance $\left(P_{\mathrm{n}}^{\prime}-I\right)$;

444 Parameter reflecting the maximum, potential, light-saturated, rate of photosynthesis in 445 model $2\left(P_{\mathrm{s}}\right)$;

446 Photosynthetic pigment molecules $(C h l)$;

447 Excited state of photosynthetic pigment molecules $\left(C h l^{*}\right)$. 
Ethics approval and consent to participate

$450 \quad$ Not applicable

451

452 Consent for publication

453 All authors consented to the publication of this work.

454

455

Availability of data and materials

456

The datasets supporting the conclusions of this article are included within the article.

457

458

\section{Competing interests}

459

The authors declare no competing interests.

460

461

462

463 31960054).

464

465

466

467

468

469

470

471

Acknowledgements

472 
473 Foundation of China for financial support in this research. We gratefully acknowledge the

474

475

476

477

478

479

480

481

482

483

484

485

486

487

488

489

490

491

492

493

494

495 anonymous reviewers for their constructive and positive comments. I also would like to express my deepest thanks to my family in Ji'an city, China for their love and support.

\section{Authors' information}

SBW is currently a Professor at Fudan University, China. ZPY is currently a Professor at Jinggangshan University, China. XLY is currently a Ph.D. student at Fudan University, China. LHL is a research assistant at Jinggangshan University, China. ZKY and XYW are two graduate students at Fudan University.

\section{References}

1. Novak T, Godrijan J, Pfannkuchen DM, Djakovac T, Medic N, Ivancic I, Mlakar M, Gasparovic B (2019) Global warming and oligotrophication lead to increased lipid production in marine phytoplankton. Science of the Total Environment 668, 171-183.

2. Kwiatkowski L, Aumont O, Bopp L, Ciais P (2018) The impact of variable phytoplankton stoichiometry on projections of primary production, food quality, and carbon uptake in the global ocean. Global Biogeochemical Cycles 32, 516-528.

3. Pachiappan P, Santhanam P, Begum A, Prasath BB (2019) An Introduction to Plankton. In: Santhanam P, Begum A, Pachiappan P (ed) Basic and Applied Microalgae Biology. Berlin, Springer, pp 1-24.

4. Borowitzka M (2019) Commercial-scale production of microalgae for bioproducts. In: La Barre S, Bates SS (ed) Blue Biotechnology -Production and Use of Marine Molecules. New Jersey, Wiley, pp 33-65. 

strategies for improving biofuel production from microalgae-a critical review. Biotechnology Advances 32, 1448-1459. (2015) Phytoplankton phenology indices in coral reef ecosystems: application to oceancolor observations in the Red Sea. Remote Sensing of Environment 160, 222-234.

7. Geider RJ, MacIntyre HL (2001) Physiology and biochemistry of photosynthesis and algal carbon acquisition. In: Williams PJ le B, Thomas DN, Reynolds CS (ed) Microalgae Productivity: Carbon Assimilation in Marine and Freshwater Ecosystems. Oxford, Blackwell Science, pp 44-77.

506

8. Stephenson PG, Moore CM, Terry MJ, Zubkov MV, Bibby TS (2011) Improving photosynthesis for algal biofuels: toward a green revolution. Trends in Biotechnology 29, 615-623.

510 development of processes for efficient light utilization in photobioreactors. Journal of Applied Phycology 12, 207-218.

10. Kieselbach T, Cheregi O, Green BR, Funk C (2018) Proteomic analysis of the phycobiliprotein antenna of the cryptophyte alga Guillardia theta cultured under different 514 light intensities. Photosynthesis Research 135, 149-163. 
London, Academic press, pp 145-171.

S (2018) Effect of ammonium and high light intensity on the accumulation of lipids in Nannochloropsis oceanica (CCAP 849/10) and Phaeodactylum tricornutum (CCAP 1055/1). Biotechnology for biofuels 11, 60 . response of photosynthesis, carbon assimilation, and triacylglycerol accumulation to nitrogen starvation in the marine microalgae Isochrysis zhangjiangensis (Haptophyta). Bioresource Technology 177, 282-288. frequency to enhance lipid productivity of thermophilic algae for biofuel production. Bioresource Technology 260, 374-379. nutrients and light: testing advances in resource competition with a natural phytoplankton community. Ecology 99, 1108-1118.

16. Darvehei P, Bahri PA, Moheimani NR (2018) Model development for the growth of microalgae: A review. Renewable and Sustainable Energy Reviews 97, 233-258. and the rate of photosynthesis in phytoplankton. Ecological Modelling 42, 199-215. 

assemblages of marine phytoplankton. Journal of Marine Research 38, 687-701. 20. Crill PA (1977) The photosynthesis-light curve: A simple analog model. Journal of Theoretical Biology 64, 503-516.

21. Platt T, Jassby AD (1976) The relationship between photosynthesis and light for natural assemblages of coastal marine phytoplankton. J Phycol 12, 421-430. mathematical model. Oecologia 17, 281-291.

23. Jayaraman SK, Rhinehart RR (2015) Modeling and optimization of algae growth.

548 Industrial \& Engineering Chemistry Research 54, 8063-8071. productivity modeling: a step toward accurate assessments of full-scale algal cultivation. Biotechnology and Bioengineering 112, 987-996. Merchuck JC (2012) A mechanistic model of photosynthesis in microalgae including photoacclimation dynamics. Journal of Theoretical Biology 304, 1-15.

26. Bernard O, Remond B (2012) Validation of a simple model accounting for light and 556 temperature effect on microalgal growth. Bioresource Technology 123, 520-527. 
28. Han BP (2001) Photosynthesis-irradiance response at physiological level: a

560

561

562

563

564

565

566

567

568

569

570

571

572

573

574

575

576

577

578

579 mechanistic model. Journal of Theoretical Biology 213, 121-127.

29. Bannister TT (1979) Quantitative description of steady state, nutrient-saturated algal growth, including adaptation. Limnology and Oceanography 24, 76-96.

30. Chen B, Zou D, Ma Z, Yu P, Wu M (2019) Effects of light intensity on the photosynthetic responses of Sargassum fusiforme seedlings to future $\mathrm{CO}_{2}$ rising. Aquaculture Research 50, 116-125.

31. Hill EA, Chrisler WB, Beliaev AS, Bernstein HC (2017) A flexible microbial coculture platform for simultaneous utilization of methane and carbon dioxide from gas feedstocks. Bioresource Technology 228, 250-256.

32. Kim M, Brodersen KE, Szabó M, Larkum AWD, Raven JA, Ralph PJ, Pernice M (2018) Low oxygen affects photophysiology and the level of expression of two-carbon metabolism genes in the seagrass Zostera muelleri. Photosynthesis Research 136, 147160.

33. Ma Z, Fang T, Thring RW, Li Y, Yu H, Zhou Q, Zhao M (2015) Toxic and non-toxic strains of Microcystis aeruginosa induce temperature dependent allelopathy toward growth and photosynthesis of Chlorella vulgaris. Harmful Algae 48, 21-29.

34. Park J, Dinh TB (2019) Contrasting effects of monochromatic LED lighting on growth, pigments and photosynthesis in the commercially important cyanobacterium Arthrospira maxima. Bioresource Technology 291, 121846.

35. Ye ZP, Suggett DJ, Robakowski P, Kang HJ (2013) A mechanistic model for the 
photosynthesis-light response based on the photosynthetic electron transport of

581

582

583

584

585

586

587

588

589

590

591

592

593

594

595

596

597

598

599

600 photosystem II in C3 and C4 species. New Phytologist 199, 110-120.

36. Li X, Cai J, Liu F, Dai T, Cao W, Jiang D (2014) Exogenous abscisic acid application during grain filling in winter wheat improves cold tolerance of offspring's seedlings. Journal of Agronomy Crop Science 200, 467-478.

37. Wu A, Song Y, Van Oosterom EJ, Hammer GL (2016) Connecting biochemical photosynthesis models with crop models to support crop improvement. Frontiers in Pant Science 7, 1518.

38. Jeffrey SW, Humphrey GFJBUPDP (1975) New spectrophotometric equations for determining chlorophylls $a, b, c 1$ and $c 2$ in higher plants, algae and natural phytoplankton. Biochemie Und Physiologie Der Pflanzen 167, 191-194.

39. Bouman HA, Platt T, Doblin M, Figueiras FG, Sathyendranath S (2017) Photosynthesis-irradiance parameters of marine phytoplankton: synthesis of a global data set. Earth System Science Data 10, 1-32.

40. Kok B (1948) A critical consideration of the quantum yield of Chlorella photosynthesis. Enzymologia 13, 1-56.

41. Ye ZP (2012) Nonlinear optical absorption of photosynthetic pigment molecules in leaves. Photosynthesis Research 112, 31-37.

42. Ooms MD, Dinh CT, Sargent EH, Sinton D (2016) Photon management for augmented photosynthesis. Nature Communications 7, 12699.

43. Baly ECC (1935) The kinetics of photosynthesis. Proceedings of the Royal Society 
601

602

603

604

605

606

607

608

609

610

611

612

613

614

615

616

617

618

619

620

621

622

of London 149, 596-596.

44. Vu MTT, Douëtte C, Rayner TA, Thoisen C, Nielsen SrL, Hansen BW (2016) Optimization of photosynthesis, growth, and biochemical composition of the microalga Rhodomonas salina - an established diet for live feed copepods in aquaculture. Journal of Applied Phycology 28, 1485-1500.

45. Stawiarski B, Buitenhuis ET, Fallens M (2018) The physiological response of seven strains of picophytoplankton to light, and its representation in a dynamic photosynthesis model. Limnology Oceanography 63, 367-380.

46. Chisti Y (2007) Biodiesel from microalgae. Biotechnology Advances 25, 294-306.

47. Ehteshami F, Romano N, Ramezani Fard E, Hoseinzadeh Sahafi H (2017) Effect of different dietary microalgae combinations on growth and survival of black - lip pearl oyster (Pinctada margaritifera) larvae and the feasibility of replacing microalgae with a dietary lipid emulsion. Aquaculture Nutrition 23, 671-680.

48. Qian Y, Liu Z, Chen Y, Zhu D, Na L (2018) Modelling the impact of hydrodynamic turbulence on the competition between Microcystis and Chlorella for light. Ecological Modelling 370, 50-58.

49. Yang X, Liu L, Wang S (2019) A strategy of high-efficient nitrogen removal by an ammonia-oxidizing bacterium consortium. Bioresource Technology 275, 216-224. 


\section{Table and Figure captions}

625 Table 1 The Chlorophyll $a$ content and cell number profiles of seven phytoplankton 626 cultures.

627 Table 2 Comparison of the results fitted by Models 1, 2, 3 and 4 with measured data in 628 marine phytoplankton.

629 Table 3 Comparison of the results fitted by Models 1, 2, 3 and 4 with measured data in 630 freshwater phytoplankton.

631 Table 4 Comparison of $P_{\mathrm{s}}$ and $P_{\text {nmax }}\left(\mu \mathrm{mol} \mathrm{O} 2 \cdot \mathrm{mg}^{-1} \mathrm{Cha} \cdot \mathrm{h}^{-1}\right)$ calculated by model 2 with 632 measured values

633 Fig. 1 Model 2, Model 3 and Model 4 responses of the net photosynthetic rate $\left(P_{\mathrm{n}}\right)$ versus 634 irradiance intensity $(I)$ determined for the different values of the fundamental parameters, respectively. (a) and (b) were obtained by Model 2, (c) and (d) were obtained by Model 3, and (e) and (f) were obtained by Model 4.

Fig. 2 The $P-I$ curves (A) and $P^{\prime}-I$ curves (B) of Isochrysis galbana, Dunaliella salina and Platymonus subcordiformis.

Fig. 3 The $P-I$ curves (A) and $P^{\prime}-I$ curves (B) of Microcystis aeruginosa, Microcystis wesenbergii, Scenedesmus obliquus and Chlorococcum sp..

Fig. 4 Schematic representation of the mechanism of photosynthesis consisting of 642 biophysical and biochemical processes.

643 Fig. 5 The $P-I$ curves produced by the model 2 at $\beta=0$ and $\beta>0$. 
648 Table 1 The Chlorophyll $a$ content and cell number profile of seven phytoplankton cultures.

\begin{tabular}{llll}
\hline Strains & Chl $a\left(\mathrm{mg} \mathrm{L}^{-1}\right)$ & Cell density $\left(10^{4}\right.$ cells $\left.\mathrm{mL}^{-1}\right)$ & Cell size $(\mu \mathrm{m})$ \\
\hline Isochrysis galbana & $1.647 \pm 0.015$ & $641.00 \pm 5.95$ & $5.8 \pm 0.4$ \\
Dunaliella salina & $2.778 \pm 0.077$ & $103.00 \pm 7.00$ & $9.8 \pm 0.2$ \\
Platymonus subcordiformis & $2.297 \pm 0.027$ & $100.33 \pm 3.38$ & $10.0 \pm 0.1$ \\
Microcystis aeruginosa FACHB-905 & $1.320 \pm 0.005$ & $669.67 \pm 12.35$ & $4.3 \pm 0.4$ \\
Microcystis wesenbergii FACHB-1112 & $1.739 \pm 0.012$ & $723.33 \pm 5.18$ & $5.1 \pm 0.2$ \\
Scenedesmus obliquus FACHB-116 & $1.318 \pm 0.027$ & $145.33 \pm 6.64$ & $8.1 \pm 0.5$ \\
Chlorococcum sp. FACHB-1556 & $4.158 \pm 0.077$ & $908.67 \pm 14.08$ & $6.0 \pm 1.2$ \\
\hline
\end{tabular}

650 Table 2 Comparison of results fitted by Model 1,2, 3 and 4 with measured data in marine 651 phytoplankton.

\begin{tabular}{|c|c|c|c|c|c|c|}
\hline \multirow[t]{2}{*}{ Models } & \multicolumn{6}{|c|}{ Photosynthetic parameters } \\
\hline & $\begin{array}{l}\alpha\left(\mu \mathrm{mol} \mathrm{O} 2 \mathrm{mg}^{-1}\right. \\
\mathrm{Chl} a \mathrm{~h}^{-1} / \mu \mathrm{mol} \\
\left.\text { photons } \mathrm{m}^{-2} \mathrm{~s}^{-1}\right)\end{array}$ & $\begin{array}{l}P_{\mathrm{nmax}}(\mu \mathrm{mol} \\
\mathrm{O}_{2} \mathrm{mg}^{-1} \mathrm{Chl} a \\
\left.\mathrm{~h}^{-1}\right)\end{array}$ & $\begin{array}{l}I_{\mathrm{sat}}(\mu \mathrm{mol} \\
\left.\text { photons } \mathrm{m}^{-2} \mathrm{~s}^{-1}\right)\end{array}$ & $\begin{array}{l}I_{\mathrm{c}}(\mu \mathrm{mol} \\
\left.\text { photons } \mathrm{m}^{-2} \mathrm{~s}^{-1}\right)\end{array}$ & $\begin{array}{l}R_{\mathrm{n}}(\mu \mathrm{mol} \mathrm{O} 2 \\
\left.\mathrm{mg}^{-1} \mathrm{Chl} a \mathrm{~h}^{-1}\right)\end{array}$ & $R^{2}$ \\
\hline \multicolumn{7}{|c|}{ Isochrysis galbana } \\
\hline Model 1 & $0.411 \pm 0.032^{\mathrm{a}}$ & $119.51 \pm 4.72^{\mathrm{a}}$ & $229.90 \pm 13.60^{\mathrm{b}}$ & $63.12 \pm 2.33^{\mathrm{a}}$ & $25.97 \pm 2.54^{\mathrm{a}}$ & $0.981 \pm 0.007^{\mathrm{a}}$ \\
\hline Model 2 & $0.468 \pm 0.037^{\mathrm{a}}$ & $97.45 \pm 3.02^{\mathrm{b}}$ & $709.60 \pm 26.89^{a}$ & $56.71 \pm 2.41^{\mathrm{a}}$ & $26.59 \pm 2.60^{\mathrm{a}}$ & $0.986 \pm 0.007^{\mathrm{a}}$ \\
\hline Model 3 & $0.373 \pm 0.020^{\mathrm{a}}$ & $97.55 \pm 3.37^{\mathrm{b}}$ & $699.26 \pm 32.19^{\mathrm{a}}$ & $65.51 \pm 3.48^{\mathrm{a}}$ & $23.98 \pm 1.95^{\mathrm{a}}$ & $0.989 \pm 0.007^{\mathrm{a}}$ \\
\hline Model 4 & $0.482 \pm 0.037^{\mathrm{a}}$ & $98.33 \pm 3.20^{\mathrm{b}}$ & $766.17 \pm 24.38^{\mathrm{a}}$ & $61.06 \pm 2.82^{\mathrm{a}}$ & $26.63 \pm 2.44^{\mathrm{a}}$ & $0.986 \pm 0.008^{a}$ \\
\hline Measured & & $\approx 94.14$ & $\approx 800$ & $\approx 62$ & $\approx 24.29$ & \\
\hline \multicolumn{7}{|c|}{ Dunaliella salina } \\
\hline Model 1 & $0.874 \pm 0.023^{\mathrm{c}}$ & $123.09 \pm 5.88^{\mathrm{a}}$ & $116.90 \pm 23.87^{\mathrm{c}}$ & $23.87 \pm 1.66^{\mathrm{a}}$ & $20.92 \pm 1.97^{\mathrm{a}}$ & $0.944 \pm 0.016^{\mathrm{b}}$ \\
\hline Model 2 & $1.006 \pm 0.033^{\mathrm{b}}$ & $113.73 \pm 6.24^{\mathrm{a}}$ & $453.39 \pm 6.87^{b}$ & $21.27 \pm 1.75^{\mathrm{a}}$ & $21.39 \pm 1.81^{\mathrm{a}}$ & $0.990 \pm 0.001^{\mathrm{a}}$ \\
\hline Model 3 & $0.918 \pm 0.058^{\mathrm{bc}}$ & $114.45 \pm 6.24^{\mathrm{a}}$ & $444.33 \pm 6.04^{b}$ & $23.09 \pm 2.29^{\mathrm{a}}$ & $19.89 \pm 1.14^{\mathrm{a}}$ & $0.989 \pm 0.007^{\mathrm{a}}$ \\
\hline Model 4 & $1.202 \pm 0.037^{\mathrm{a}}$ & $113.31 \pm 5.87^{\mathrm{a}}$ & $510.24 \pm 2.92^{\mathrm{a}}$ & $21.67 \pm 1.93^{\mathrm{a}}$ & $23.30 \pm 1.93^{\mathrm{a}}$ & $0.983 \pm 0.002^{\mathrm{a}}$ \\
\hline Measured & & $\approx 119.24$ & $\approx 500$ & $\approx 23$ & $\approx 20.25$ & \\
\hline \multicolumn{7}{|c|}{ Platymonus subcordiformis } \\
\hline Model 1 & $1.975 \pm 0.055^{\mathrm{d}}$ & $107.96 \pm 5.58^{\mathrm{a}}$ & $41.25 \pm 1.62^{\mathrm{d}}$ & $13.40 \pm 2.21^{\mathrm{a}}$ & $26.32 \pm 3.93^{\mathrm{a}}$ & $0.883 \pm 0.010^{c}$ \\
\hline Model 2 & $2.479 \pm 0.023^{\mathrm{c}}$ & $94.64 \pm 6.65^{\mathrm{a}}$ & $212.36 \pm 7.80^{c}$ & $11.05 \pm 1.65^{\mathrm{a}}$ & $27.45 \pm 4.30^{\mathrm{a}}$ & $0.975 \pm 0.009^{a}$ \\
\hline Model 3 & $2.834 \pm 0.056^{\mathrm{b}}$ & $95.59 \pm 6.63^{\mathrm{a}}$ & $251.97 \pm 9.73^{b}$ & $10.82 \pm 1.87^{\mathrm{a}}$ & $26.13 \pm 4.26^{\mathrm{a}}$ & $0.958 \pm 0.013^{\mathrm{ab}}$ \\
\hline Model 4 & $3.640 \pm 0.031^{\mathrm{a}}$ & $92.20 \pm 6.56^{\mathrm{a}}$ & $299.55 \pm 10.72^{\mathrm{a}}$ & $9.68 \pm 1.71^{\mathrm{a}}$ & $28.36 \pm 4.21^{\mathrm{a}}$ & $0.934 \pm 0.013^{\mathrm{b}}$ \\
\hline Measured & & $\approx 100.13$ & $\approx 150$ & $\approx 14$ & $\approx 24.49$ & \\
\hline
\end{tabular}


656 Table 3 Comparison of results fitted by Model 1, 2, 3 and 4 with measured data in freshwater 657 phytoplankton.

\begin{tabular}{|c|c|c|c|c|c|c|}
\hline \multirow[t]{2}{*}{ Models } & \multicolumn{6}{|c|}{ Photosynthetic parameters } \\
\hline & $\begin{array}{l}\alpha\left(\mu \mathrm{mol} \mathrm{O} 2 \mathrm{mg}^{-1}\right. \\
\mathrm{Chl} a \mathrm{~h}^{-1} / \mu \mathrm{mol} \\
\left.\text { photons } \mathrm{m}^{-2} \mathrm{~s}^{-1}\right)\end{array}$ & $\begin{array}{l}P_{\mathrm{nmax}}(\mu \mathrm{mol} \mathrm{O} 2 \\
\left.\mathrm{mg}^{-1} \mathrm{Chl} a \mathrm{~h}^{-1}\right)\end{array}$ & $\begin{array}{l}I_{\mathrm{sat}}(\mu \mathrm{mol} \\
\left.\text { photons } \mathrm{m}^{-2} \mathrm{~s}^{-1}\right)\end{array}$ & $\begin{array}{l}I_{\mathrm{c}}(\mu \mathrm{mol} \\
\left.\text { photons } \mathrm{m}^{-2} \mathrm{~s}^{-1}\right)\end{array}$ & $\begin{array}{l}R_{\mathrm{d}}(\mu \mathrm{mol} \mathrm{O} 2 \\
\left.\mathrm{mg}^{-1} \mathrm{Chl} a \mathrm{~h}^{-1}\right)\end{array}$ & $R^{2}$ \\
\hline \multicolumn{7}{|c|}{ Microcystis aeruginosa } \\
\hline Model 1 & $2.404 \pm 0.103^{b}$ & $260.46 \pm 10.72^{\mathrm{a}}$ & $97.83 \pm 2.42^{\mathrm{d}}$ & $10.57 \pm 1.12^{\mathrm{a}}$ & $25.63 \pm 3.86^{\mathrm{a}}$ & $0.721 \pm 0.047^{b}$ \\
\hline Model 2 & $2.416 \pm 0.074^{\mathrm{b}}$ & $290.74 \pm 15.09^{\mathrm{a}}$ & $380.17 \pm 4.89^{\mathrm{b}}$ & $9.47 \pm 1.05^{\mathrm{a}}$ & $22.92 \pm 2.75^{\mathrm{a}}$ & $0.973 \pm 0.010^{\mathrm{a}}$ \\
\hline Model 3 & $1.770 \pm 0.026^{\mathrm{c}}$ & $296.37 \pm 14.89^{\mathrm{a}}$ & $340.82 \pm 4.49^{c}$ & $10.26 \pm 2.54^{\mathrm{a}}$ & $18.23 \pm 4.61^{\mathrm{a}}$ & $0.969 \pm 0.015^{\mathrm{a}}$ \\
\hline Model 4 & $2.967 \pm 0.067^{\mathrm{a}}$ & $283.55 \pm 14.53^{\mathrm{a}}$ & $415.25 \pm 2.33^{\mathrm{a}}$ & $9.53 \pm 1.05^{\mathrm{a}}$ & $26.86 \pm 2.75^{\mathrm{a}}$ & $0.964 \pm 0.007^{\mathrm{a}}$ \\
\hline Measured & & $\approx 290.83$ & $\approx 400$ & $\approx 10$ & $\approx 18.27$ & \\
\hline \multicolumn{7}{|c|}{ Microcystis wesenbergii } \\
\hline Model 1 & $1.879 \pm 0.039^{\mathrm{b}}$ & $184.72 \pm 2.57^{\mathrm{c}}$ & $82.57 \pm 2.56^{\mathrm{d}}$ & $15.85 \pm 1.68^{\mathrm{a}}$ & $29.73 \pm 2.91^{\mathrm{ab}}$ & $0.758 \pm 0.031^{\mathrm{b}}$ \\
\hline Model 2 & $1.920 \pm 0.030^{\mathrm{b}}$ & $195.32 \pm 1.50^{\mathrm{ab}}$ & $352.20 \pm 7.29^{\mathrm{b}}$ & $14.70 \pm 1.87^{\mathrm{a}}$ & $28.15 \pm 2.44^{\mathrm{ab}}$ & $0.974 \pm 0.006^{\mathrm{a}}$ \\
\hline Model 3 & $1.309 \pm 0.074^{\mathrm{c}}$ & $201.37 \pm 2.94^{\mathrm{a}}$ & $322.50 \pm 6.96^{c}$ & $15.50 \pm 2.37^{\mathrm{a}}$ & $20.46 \pm 3.90^{\mathrm{b}}$ & $0.978 \pm 0.007^{\mathrm{a}}$ \\
\hline Model 4 & $2.474 \pm 0.071^{\mathrm{a}}$ & $188.62 \pm 2.31^{\mathrm{bc}}$ & $389.62 \pm 9.62^{\mathrm{a}}$ & $14.81 \pm 1.47^{\mathrm{a}}$ & $33.19 \pm 2.31^{\mathrm{a}}$ & $0.954 \pm 0.011^{\mathrm{a}}$ \\
\hline Measured & & $\approx 201.29$ & $\approx 400$ & $\approx 15$ & $\approx 23.73$ & \\
\hline \multicolumn{7}{|c|}{ Scenedesmus obliquus } \\
\hline Model 1 & $1.499 \pm 0.019^{c}$ & $265.88 \pm 5.70^{\mathrm{a}}$ & $159.64 \pm 1.84^{\mathrm{d}}$ & $17.82 \pm 3.32^{\mathrm{a}}$ & $26.61 \pm 4.67^{\mathrm{a}}$ & $0.912 \pm 0.006^{\mathrm{b}}$ \\
\hline Model 2 & $1.581 \pm 0.010^{\mathrm{b}}$ & $268.80 \pm 5.21^{\mathrm{a}}$ & $527.39 \pm 8.93^{b}$ & $15.24 \pm 3.18^{\mathrm{a}}$ & $24.05 \pm 4.91^{\mathrm{a}}$ & $0.989 \pm 0.002^{\mathrm{a}}$ \\
\hline Model 3 & $1.268 \pm 0.030^{\mathrm{d}}$ & $268.70 \pm 5.25^{\mathrm{a}}$ & $481.60 \pm 8.51^{\mathrm{c}}$ & $15.34 \pm 3.74^{\mathrm{a}}$ & $19.25 \pm 4.59^{\mathrm{a}}$ & $0.989 \pm 0.001^{\mathrm{a}}$ \\
\hline Model 4 & $1.751 \pm 0.021^{\mathrm{a}}$ & $268.11 \pm 4.98^{\mathrm{a}}$ & $561.94 \pm 8.40^{\mathrm{a}}$ & $15.82 \pm 3.15^{\mathrm{a}}$ & $26.29 \pm 4.79^{\mathrm{a}}$ & $0.987 \pm 0.002^{\mathrm{a}}$ \\
\hline Measured & & $\approx 267.37$ & $\approx 400$ & $\approx 15$ & $\approx 19.91$ & \\
\hline \multicolumn{7}{|c|}{ Chlorococcum sp. } \\
\hline Model 1 & $0.979 \pm 0.007^{\mathrm{c}}$ & $83.86 \pm 4.98^{\mathrm{a}}$ & $68.66 \pm 4.47^{c}$ & $17.00 \pm 1.80^{\mathrm{a}}$ & $16.66 \pm 1.82^{\mathrm{a}}$ & $0.935 \pm 0.009^{c}$ \\
\hline Model 2 & $1.190 \pm 0.020^{\mathrm{b}}$ & $75.25 \pm 3.79^{\mathrm{a}}$ & $311.04 \pm 17.27^{b}$ & $14.59 \pm 1.52^{\mathrm{a}}$ & $17.43 \pm 2.09^{\mathrm{a}}$ & $0.984 \pm 0.001^{\mathrm{a}}$ \\
\hline Model 3 & $1.247 \pm 0.022^{\mathrm{b}}$ & $76.15 \pm 3.89^{\mathrm{a}}$ & $339.85 \pm 15.19^{b}$ & $15.02 \pm 1.76^{\mathrm{a}}$ & $16.82 \pm 2.09^{\mathrm{a}}$ & $0.979 \pm 0.002^{\mathrm{ab}}$ \\
\hline Model 4 & $1.572 \pm 0.024^{\mathrm{a}}$ & $74.59 \pm 4.23^{\mathrm{a}}$ & $396.06 \pm 15.93^{\mathrm{a}}$ & $13.87 \pm 1.59^{\mathrm{a}}$ & $18.64 \pm 2.18^{\mathrm{a}}$ & $0.964 \pm 0.001^{\mathrm{b}}$ \\
\hline Measured & & $\approx 76.06$ & $\approx 400$ & $\approx 15$ & $\approx 15.03$ & \\
\hline
\end{tabular}


665 Table 4 Comparison of $P_{\mathrm{s}}, P_{\text {nmax }}\left(\mu \mathrm{mol} \mathrm{O}_{2} \mathrm{mg}^{-1} \mathrm{Chl} a \mathrm{~h}^{-1}\right)$ calculated by model 2 with measured value

\begin{tabular}{llllllll}
\hline Parameter & Isochrysis & Dunaliella & Platymonus & Microcystis & Microcystis & Scenedesmus & Chlorococcum \\
& galbana & salina & subcordiformis & aeruginosa & wesenbergii & obliquus & sp. \\
\hline$P_{\mathrm{s}}(\beta=0)$ & $135.44 \pm 6.59$ & $144.28 \pm 10.86$ & $133.39 \pm 6.73$ & $328.48 \pm 18.27$ & $235.77 \pm 3.70$ & $311.42 \pm 7.37$ & $96.21 \pm 5.71$ \\
$P_{\mathrm{s}}(\beta>0)$ & $14188.6 \pm 13735.8$ & $196.08 \pm 31.06$ & $135.23 \pm 7.45$ & $1163.4 \pm 615.5$ & $415.53 \pm 29.50$ & $943.8 \pm 282.4$ & $107.02 \pm 5.53$ \\
$P_{\text {nmax }}$ & $97.45 \pm 3.02$ & $113.73 \pm 6.24$ & $94.64 \pm 6.65$ & $290.74 \pm 15.09$ & $195.32 \pm 1.50$ & $268.80 \pm 5.21$ & $75.25 \pm 3.79$ \\
Observations & $\approx 94$ & $\approx 119$ & $\approx 100$ & $\approx 290$ & $\approx 200$ & $\approx 267$ & $\approx 75$ \\
\hline
\end{tabular}

666

667

668

669

670

671

672

673

674

675

676

677

678

679

680

681

682

683 

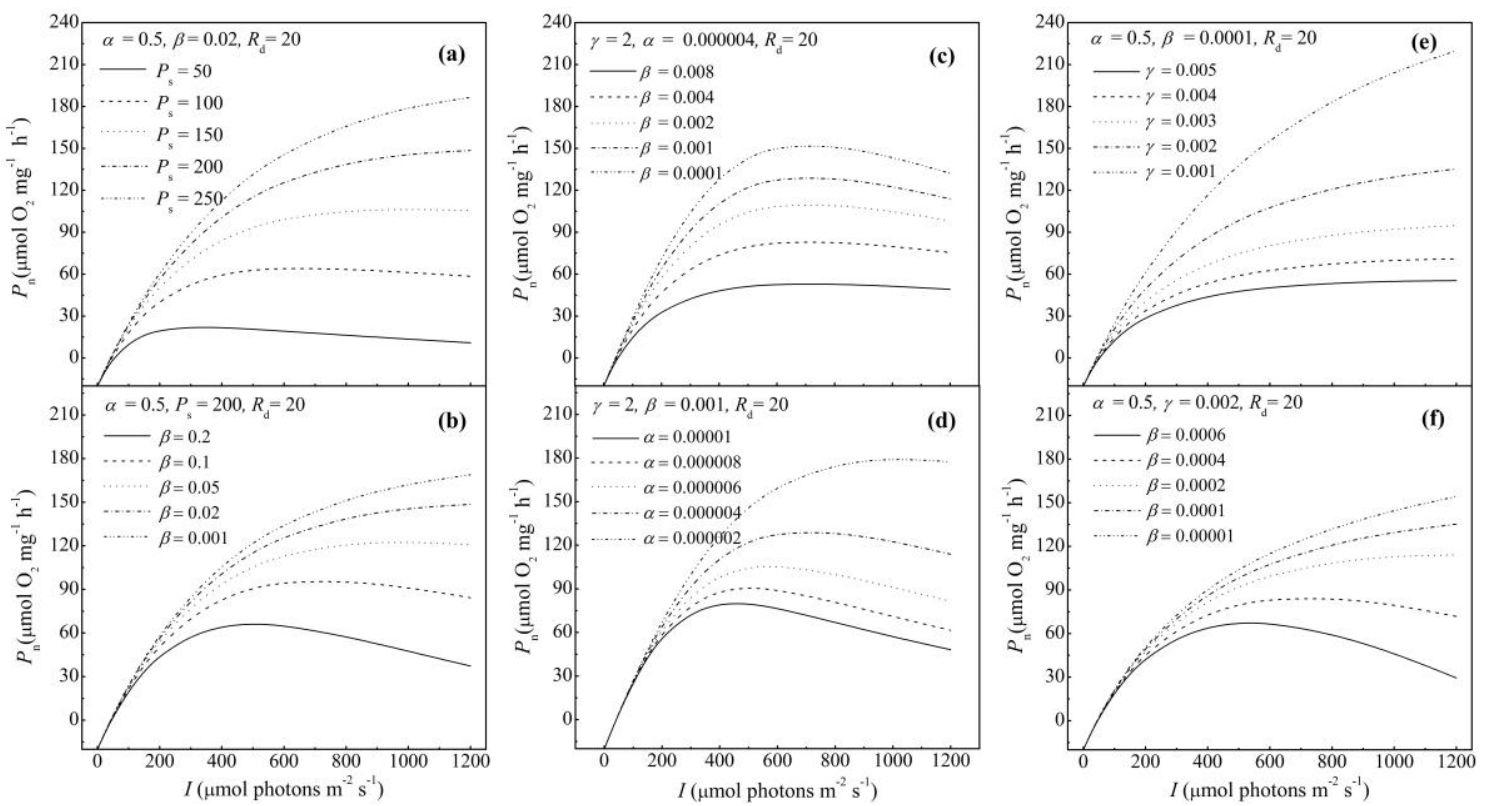

Fig. 1 Model 2, Model 3 and Model 4 responses of the net photosynthetic rate $\left(P_{\mathrm{n}}\right)$ versus irradiance
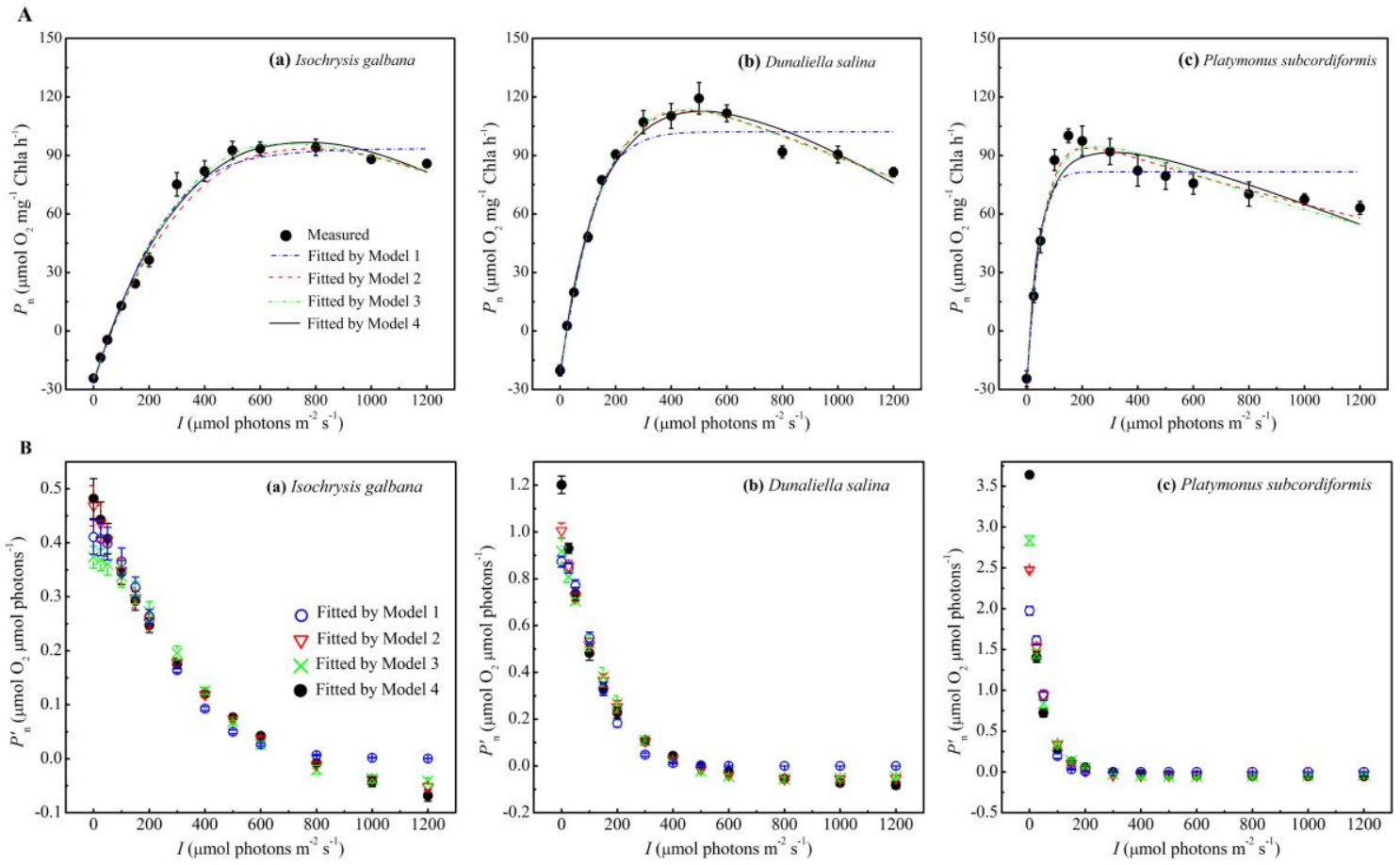

Fig. 2 The $P$-I curves (A) and $P^{\prime}-I$ curves (B) in Isochrysis galbana, Dunaliella salina and Platymonus 
694
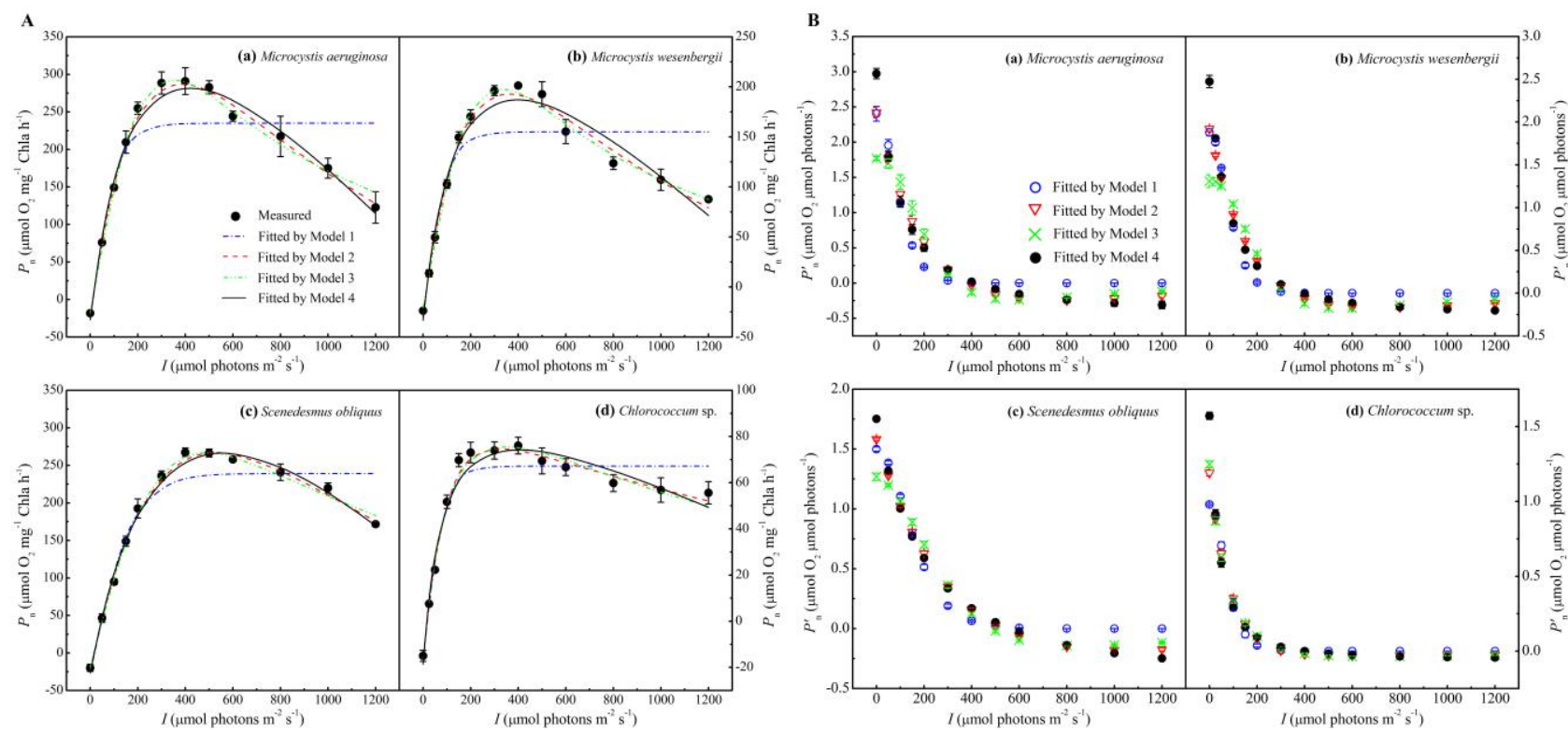

695

696 Fig. 3 The $P-I$ curves (A) and $P^{\prime}-I$ curves (B) in Microcystis aeruginosa, Microcystis wesenbergii,

697 Scenedesmus obliquus and Chlorococcum sp..

698

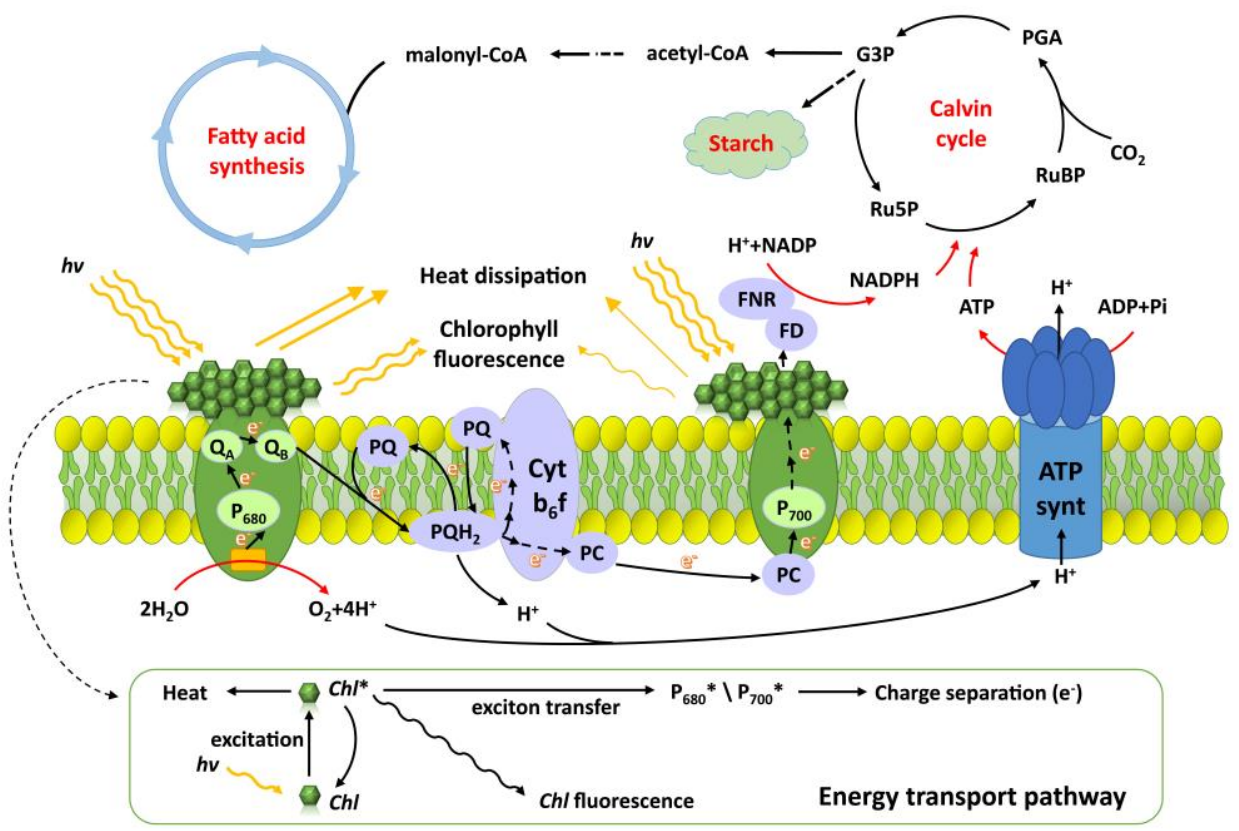

700 Fig. 4 Schematic representation of mechanism of photosynthesis consisted of biophysical and 701 biochemical processes. 

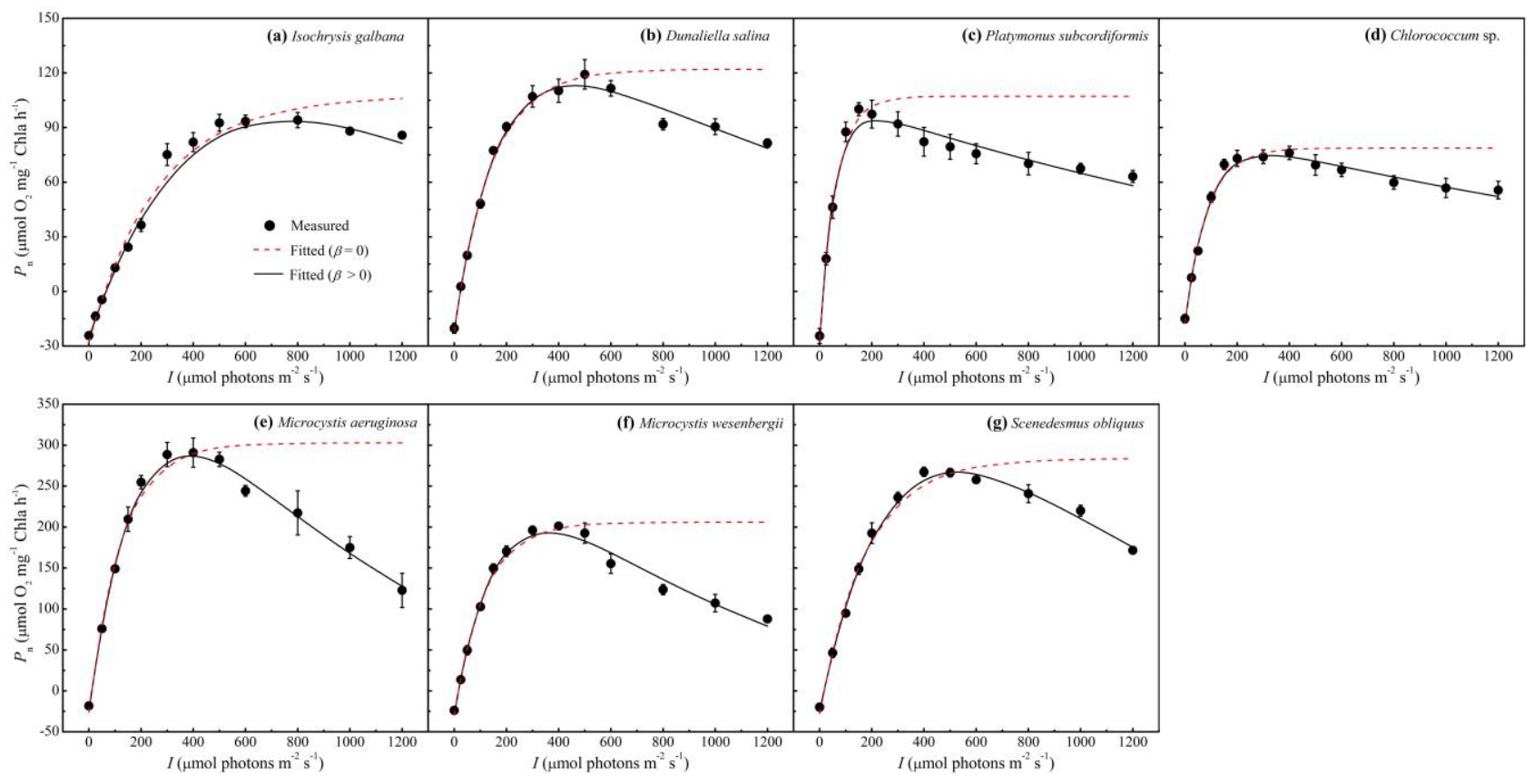

704 Fig. 5 The $P-I$ curves produced by the model 2 at $\beta=0$ and $\beta>0$. 